\title{
ІНДИВІДУАЛІЗАЦІЯ НАВЧАЛЬНОГО ПРОЦЕСУ ПРИ ВИКЛАДАННІ КЛІНІЧНИХ ДИСЦИПЛІН СТУДЕНТАМ ВИЩОГО МЕДИЧНОГО НАВЧАЛЬНОГО ЗАКЛАДУ
}

О. О. Філіпець

Буковинський дерэсавний медччний університет

\section{INDIVIDUALIZATION OF EDUCATION IN TEACHING CLINICAL DISCIPLINES TO THE STUDENTS OF HIGHER MEDICAL EDUCATIONAL INSTITUTION}

\author{
O. O. Filipets
}

\author{
Bukovyna State Medical University
}

\begin{abstract}
У статті висвітлені основні принципи індивідуального підходу до професійної підготовки студентів у вищому медичному навчальному закладі в умовах кредитно-модульної системи навчання. Наведено способи та етапи реалізації індивідуалізованого навчання при викладанні клінічних дисциплін, що є необхідним для виявлення характерних професійних рис на теоретичному та практичному рівнях навчання, підвищення рівня активності студентів, їх творчої та наукової реалізації, формування професійної мотивації майбутніх спеціалістів.
\end{abstract}

The article highlights the basic principles of individual approach to professional training of students in Higher Medical Educational Institution under conditions of credit-modular system of education. The methods and stages of realization of individualized teaching that are required for development of specific professional features at theoretical and practical levels, increase of the students' activity, as well as their creative and scientific realization, formation of professional motivation of the future specialists are presented.

Вступ. Метою Національної стратегії розвитку освіти в Україні на період до 2021 року є підвищення доступності якісної освіти, яка відповідає вимогам інноваційного розвитку суспільства, а також забезпечення особистісного розвитку людини згідно з її індивідуальними здібностями та потребами. При цьому завданнями Національної стратегії є модернізація та системне підвищення якості освіти, забезпечення сучасного психолого-педагогічного та науково-методичного супроводу навчального процесу, використання сучасних засобів навчання з урахуванням світового досвіду.

Необхідність підвищення якості професійної підготовки майбутніх спеціалістів у медичному ВНЗ пов'язана 3 науково-технічними досягненнями сучасної медицини, соціально-економічними перетвореннями, а також зі швидкозмінними вимогами сучасного ринку праці. У таких умовах виникає потреба у високоінтелектуальних фахівцях, пристосованих до інтенсивної праці, здатних розвивати професійно важливі якості та здійснювати безперервну

() О. О. Філіпець освіту. Це, у свою чергу, вимагає застосування нового підходу до професійної підготовки студентів, що передбачає підвищення їх активності, формування особистісних рис, розвитку здібностей та вихід за межі рутинного засвоєння знань і вмінь.

Основна частина. Одним із провідних підходів до процесу навчання в умовах оновлення системи вищої медичної освіти є індивідуальний підхід-така організація навчальної діяльності студента, в якій процес навчання і практична робота проводяться на тлі індивідуального педагогічного супроводу [2]. Це одна $з$ активних форм навчання, що передбачає здійснення навчального процесу з урахуванням індивідуально-особистісних рис студента, які значною мірою впливають на їх поведінку в різноманітних життєвих ситуаціях.

Результатами успішної реалізації індивідуального підходу стають підвищення самостійності студентів у навчальній діяльності, самореалізація у навчанні та продуктивне засвоєння програми дисципліни. Особливо важливими для майбутніх лікарів $є$ можливість обгрунтованого вибору професійного шляху відповідно до їх потреб та інтересів, формування професій- 
но значущих якостей особистості, готовність до прояву ініціативи, прагнення до самовдосконалення, освіти та саморозвитку [4].

Індивідуалізація навчання при викладанні клінічних дисциплін грунтується на персональних відмінностях якостей студентів: рівні знань, умінь і навичок, ставленні до навчання та майбутньої професії тощо. Завдяки кредитно-модульній системі студент сам може обирати рівень вивчення предмета. Перший рівень $€$ доступним для всіх студентів, він забезпечує засвоєння цілісної картини матеріалу, вміння відповідати на репродуктивні питання, опанування методик виконання найбільш розповсюджених лікарських дій. Другий рівень вимагає аналізу матеріалу завдяки розширенню і поглибленню знань, одержаних під час засвоєння першого рівня. Третій рівень містить знання, які $є$ необов'язковими для всіх, передбачає інтенсивну самостійну роботу, тому забезпечує студенту найвищу оцінку [3].

Індивідуальний підхід реалізовується й у вигляді надання студентам завдань різної складності від написання робіт із окремих дисциплін (у вигляді рефератів або проектів) до спільної науково-дослідницької роботи студентів і викладачів, спільних публікацій, підготовки доповідей, участі у наукових товариствах. Індивідуальні завдання за складністю і характером повинні відповідати можливостям студента, передбачати його особисту самостійну участь, а також містити в собі багато різноманітних проблем і питань, які виникають на лекціях і практичних заняттях [5]. Все це сприяє виявленню характерних професійних рис на теоретичному та практичному етапах навчання, підвищує рівень активності студентів, забезпечує творчу та наукову реалізацію. Крім цього, специфічною метою індивідуалізації є формування професійної мотивації та успішне входження у середовище кваліфікованих спеціалістів.

У свою чергу, недостатня диференційованість навчального процесу може бути пов'язана з однаковим для всіх навчальним планом, викладанням предметів за єдиними навчальними програмами, використанням стандартних форм і методів навчання, які залишають порівняно невеликі можливості для творчої роботи. Викладачі часто накладають однакові вимоги на усіх без винятку студентів, не враховуючи

\section{Література}

1. Дражниця С. А. Диференціація навчання: актуальні проблеми та пріоритетні шляхи реалізації в інтегрованому освітньому просторі ВНЗ / С. А. Дражниця, О. М. Дражни- їх особистісних можливостей та інтересів. У результаті виникає низька навчальна мотивація студентів, недостатня реалізація їх потенціалу, неусвідомлення власних здібностей і можливостей, а іноді й випадковість у виборі спеціальності та шляхів продовження освіти. Провідну роль у цьому відіграє "неактивність" педагогів, небажання керувати пізнавальною діяльністю студентів, здійснювати підбір різних форм організації цієї діяльності та методів і засобів навчання з урахуванням підготованості студентів, мотивів та очікуваних результатів навчання [6].

Для подолання таких проблем викладачу слід дотримуватись певних етапів керування індивідуальним навчанням. Першим етапом повинен бути діагностичний, завданням якого є виявлення проблем, труднощів у пізнавальній діяльності студентів у процесі навчання та визначення диференційованих груп. На цьому етапі викладач повинен оцінити здібності студента і можливості до засвоєння матеріалу навчальної дисципліни, а також рівень оволодіння необхідними предметними знаннями, вміннями і навичками. Слід також визначити пізнавальні інтереси те, наскільки студент зацікавлений у самонавчанні, самоосвіті, саморозвитку. Надзвичайно важливим моментом є оцінка орієнтації на майбутню професію, тобто того, наскільки у студента сформована потреба у набутті професійно-специфічних якостей і компетенцій. Після цього необхідно переходити до другого етапу - проектувального, на якому відбувається підбір форм, методів і засобів організації пізнавальної діяльності. Третій етап є формувальним, на ньому розвиваються професійні якості майбутніх спеціалістів з урахуванням індивідуальних здібностей. При цьому диференціація на всіх етапах повинна бути засобом стимулювання студентів до навчання та активізації їх пізнавальної діяльності, творчого розвитку особистості, створення бажання до самоосвіти та самовдосконалення [1].

Висновок. Індивідуалізація роботи викладача зі студентом є невідкладною складовою навчального процесу в сучасних умовах. При цьому, поряд із засвоєнням студентами базових знань, умінь і навичок, стимулюється розвиток творчих і комунікативних здібностей особи, а також відбувається підготовка студентів до діяльності за обраною професією.

ця, О. А. Дудар // Збірник наукових праць Хмельницького інституту соціальних технологій Університету “Україна". 2010. -№ 2.-C. 178-183. 


\section{ВДОСКОНАЛЕННЯ ВИЩОЇ МЕДИЧНОЇ ОСВІТИ}

2. Ельбрехт О. М. Проблема актуалізації педагогічних знань у підготовці фахівців у вищих навчальних закладах / О. М. Ельбрехт // Наукові записки. Серія: Педагогіка. -2010. -№ 1.- С. 242-245.

3. Мельникова И. Ю. Особенности медицинского образования и роль преподавателя вуза в образовательном процессе на современном этапе / И. Ю. Мельникова, М. Г. Романцов // Международный журнал экспериментального образования.-2013. - № 11.-С. 47-52.

4. Парахонский А. П. Анализ основных принципов индивидуализации и гуманизации обучения студентов /
А. П. Парахонский // Современные наукоемкие технологии. -2005. - № 6. - С. 26-27.

5. Стебльова К. К. Організація самостійної роботи студентів ВНЗ за допомогою засобів інформаційних технологій / К. К. Стебльова // Сборники научных работ НТУ "ХПИ": Проблеми та перспективи формування національної гуманітарно-технічної еліти. Вестник НТУ "ХПИ”. 2012. -№ 30.-C. 317-325.

6. Яковенко Т. В. Вимоги до педагога професійного навчання нової генерації / Т. В. Яковенко // Теорія і практика управління соціальними системами. - 2013. - № 4. С. 83-90. 